\title{
COMPENSATORY AWARD FOR UNFAIR DISMISSAL IN MALAYSIA: CRITERIONS IN ASSESSMENT OF AWARD
}

\author{
Ashgar Ali Ali Mohamed ${ }^{1 \star}$ Mohd Akram Shair Mohamed², and Farheen Baig Sardar \\ Baig $^{3}$ \\ ${ }^{1}$ Prof. Dr., International Islamic University Malaysia, ashgar@iium.edu.my \\ ${ }^{2}$ Prof. Dr., International Islamic University Malaysia, akram@iium.edu.my \\ ${ }^{3}$ Assoc. Prof. Dr., International Islamic University Malaysia, baigfarheen007@yahoo.com \\ ${ }^{*}$ Corresponding author
}

\begin{abstract}
Dismissal from employment is the prerogative of the employer emanating from various reasons such as unsatisfactory or poor work performance, incompetency, absenteeism, insubordination, stealing, assault, bullying, drunkenness, serious violation of employer's policies and practices, damaging employer's property and using employer's property for personal business, among others. The burden is on the employer to prove that the dismissed was justified. Where a dismissal was adjudged to be without just cause or excuse, the Industrial Court will award appropriate remedy and this include compensatory award. The Industrial Relations Act 1967 (IRA) merely mentioned reinstatement as the sole remedy for dismissal without just cause or excuse. The power of the Industrial Court to award monetary compensation was resolved by the former Federal Court in Assunta Hospital v Dr A Dutt [1981] 1 MLJ 105, where the Court held inter alia, that where reinstatement would not be an appropriate remedy, the Industrial Court has the power to award monetary compensation based on the provisions of section 30(4), (5) and (6) of the IRA. Although the Act did not specify the types and criterions for its assessment, nevertheless the monetary award in favour of the unfairly dismissed worker must be fair and adequate to compensate him for the loss of employment. In practice however, the assessment or measure of the monetary award is at the discretion of the Industrial Court based on the particular facts, circumstances and substantial merits of the case, and assessed in accordance with equity and good conscience under section 30(5) of the IRA. The amount however, should not be excessive to the extent of financially burdening the employer. In light of the above, this paper discusses the compensatory awards of the Industrial Court in successful unfair dismissal claims with a view of highlighting the criterions used in its assessment.
\end{abstract}

Keywords: Unfair Dismissal, Monetary Compensation, Industrial Court Award

\section{INTRODUCTION}

Where reinstatement would not be an appropriate remedy for dismissal without just cause or excuse, the Industrial Court's power to award monetary compensation is based on the provisions of section 30(4), (5) and (6) of the IRA. This was asserted by the former Federal Court in Assunta Hospital v Dr A Dutt [1981] 1 MLJ 105. The assessment of the monetary award however was left at the discretion of the Industrial Court to be determined based on the facts and circumstances of individual case and in accordance with equity and good 
conscience. To ensure uniformity and consistency in its assessment, a practice directive was issued by the President of the Industrial Court in 1987 which provides inter alia, that the monetary compensation shall comprise the following namely, back wages and compensation in lieu of reinstatement. Back wages is aimed at compensating the workman for lost benefits, which he might reasonably have expected to have had, but for the dismissal while compensation in lieu of reinstatement is intended to compensate the workman for loss of employment.

To reinforce the practice directive, the Malaysia Parliament had, vide the Industrial Relations (Amendment) Act 2007, included the general framework on the assessment of monetary compensation in the IRA which is now embodied in section $30(6 \mathrm{~A})$ of the said Act. Section 30(6A) provides that in making an award in relation to a reference to it under subsection 20(3), the Industrial Court shall take into consideration the factors as specified in the second schedule, namely:

(1) In the event that back wages are to be given, such back wages shall not exceed twenty-four months' back wages from the date of dismissal based on the last-drawn salary of the person who has been dismissed without just cause or excuse;

(2) In the case of a probationer who has been dismissed without just cause or excuse, any back wages given shall not exceed twelve months' back wages from the date of dismissal based on his last-drawn salary;

(3) Where there is post-dismissal earnings, a percentage of such earnings, to be decided by the Court, shall be deducted from the back wages given;

(4) Any relief given shall not include any compensation for loss of future earnings; and

(5) Any relief given shall take into account contributory misconduct of the workman.

Despite the above general framework on the assessment of the compensatory award, the assessment of the award has been very much at the discretion of the Industrial Court depending on the particular facts and circumstances of individual cases and assessed in accordance with equity and good conscience. In Nestle Food Storage (Sabah) Sdn Bhd v Terrence Tan Nyang Yin [2002] 1 ILR 280, the Industrial Court noted the need for concerted effort to articulate and formulate a set of principles to be adopted in the assessment of the monetary awards. In light of the above, this paper analyses the factors usually considered by the Industrial Court in determining the appropriate compensatory award for dismissal without just cause or excuse. At this juncture, it is worth noting that so long as the Industrial Court followed the correct principles in the assessment of the monetary compensation and the award not being outrageous, manifestly excessive or unreasonable, the civil courts, exercising judicial review against the Industrial Court's award, will not interfere with the said award.

\section{COMPENSATION IN LIEU OF REINSTATEMENT}

When reinstatement into former employment is not an appropriate remedy due to various reasons, the Industrial Court has the power to award the claimant compensation in lieu of reinstatement. Compensation in lieu of reinstatement is intended to compensate the claimant for the loss of his job (See Nestle Storage (Sabah) Sdn Bhd v Tenance Tan Nyang Yin [2002] 1 ILR 280). In Dr A Dutt v Assunta Hospital [1981] 1 MLJ 115, the Federal Court stated inter alia, that upon a true construction of section 30 subsections (4), (5) and (6) of the IRA, the Industrial Court may properly award monetary compensation when it considers reinstatement is not an appropriate remedy in the circumstances of the case. As stated earlier, the assessment of compensation in lieu of reinstatement is contained in the Industrial Court's practice directive of 1987 namely, at the rate of one month's salary for each completed year of service. Hence, the quantum of such compensation will depend firstly, on the number of years in respect of which the workman has been continuously employed and secondly, based on his last drawn monthly salary.

In exceptional circumstances however, the Industrial Court may award compensation in lieu of reinstatement in excess of the normal rate, a form of punitive compensation in favour of the employee. In KFC Technical Service Sdn Bhd v Industrial Court of Malaysia \& Anor [1992] 1 MLJ 564, the dismissal of the claimants was tainted with the motive of victimisation and unfair labour practice. In holding their dismissal to be without just cause or excuse, the Industrial Court awarded the claimants compensation in lieu of reinstatement at the rate of two months' salary for each year of service, as punitive compensation. Victimisation of these workers had been considered as exceptional circumstances to award compensation in excess of the ordinary rate of one month's wages for each completed year of service.

Again, in Sivabalan Poobalasingam v Kuwait Finance House (Malaysia) Berhad [2016] 1 ILR 542, the Industrial Court was faced with the issue whether the claimant's retrenchment had been carried out bona fide, thus constituting just cause or excuse for his dismissal. In this case, after his termination, the claimant's position 
had been taken over by someone else and this clearly showed that the dismissal was tainted with the motive of victimisation and unfair labour practice. The irresponsible manner by which the claimant's case had been dealt by the company was indeed a fitting and proper case for punitive compensation to be awarded. Accordingly, the Industrial Court awarded the claimant compensation in lieu of reinstatement at the rate of two months' salary for each year of service, as punitive compensation. Be that as it may, in the vast majority of successful unfair dismissal claims, the Industrial Court had awarded compensation in lieu of reinstatement at the ordinary rate of one month's wages for each completed year of service.

\subsection{Compensation In Lieu Of Reinstatement Unavailable To Employee Attaining Compulsory Retirement Age}

In Sabah Forest Industries Sdn Bhd v Industrial Court Malaysia \& Anor [2014] 4 ILR 258, the Court of Appeal held inter alia, that compensation in lieu of reinstatement does not arise in cases where the employee has passed his compulsory retirement age which is currently set at the age of 60 pursuant to section 4 of the Minimum Retirement Age Act 2012. The Court of Appeal's decision in Sabah Forest Industries Sdn Bhd was affirmed by the Federal Court, the apex court in Malaysia, in Unilever (M) Holdings Sdn Bhd v So Lai \& Anor [2014] 4 ILR 258. In Unilever (M) Holdings Sdn Bhd, the first respondent, the aggrieved employee, was dismissed without just cause or excuse by appellant company after serving the company for some 17 years. At the time of his dismissal, the first respondent was 14 months away from his mandatory retirement age. The Industrial Court in affirming the first respondent's dismissal to be without just cause or excuse, awarded him a sum of RM81,566 as compensation in lieu of reinstatement calculated based on the last drawn monthly salary of RM4,798 times 17 months' salary which was based on the number of years in service namely, 17 years. The Industrial Court's award was affirmed by the High Court in a judicial review application. The appellant's appeal to the Court of Appeal was dismissed.

On a further appeal to the Federal Court, the Court allowed the appeal and set aside the compensation in lieu of reinstatement award made by courts below. The Federal Court held inter alia, that the words 'in lieu of' signify 'instead of' and 'in place of'. Hence, the words 'compensation in lieu of reinstatement' in their ordinary and popular sense means that 'such compensation was meant to be a replacement or a substitute or an alternative to reinstatement.' It was further stated that the condition precedent for compensation in lieu of reinstatement is that the employee must be in a position or situation to be reinstated. This according to the Federal Court was fortified by the clear provision of section 20(1) of the IRA namely, 'to be reinstated in his former employment'. Hence, if a workman cannot be reinstated because he has passed the compulsory retirement age, the issue of compensation in lieu of reinstatement would not arise.

As from the above, compensation in lieu of reinstatement is not available if at the time the award was handed down by the Industrial Court the claimant had passed his compulsory retirement age. This is because the claimant could not be reinstated beyond his compulsory retirement age. There is logic in the said decision in that the payment of such compensation would not arise when a workman could not be reinstated because he had passed his compulsory retirement age. The said Federal Court's decision in Unilever (M) Holdings work unfairly against an employee who had served the company faithfully for many years but is deprived of the compensation merely because he had passed his compulsory retirement age when the awarded was handed down by the Industrial Court. But if the employee has not reached his compulsory retirement age when the award was made by the Industrial Court, he will be entitled to such compensation. In Unilever (M) Holdings case, at the time of his dismissed on 14 March 2001, the first respondent was 14 months away from his mandatory retirement age. He had served the appellant company faithfully for 17 years. However, when the award was handed down by the Industrial Court, the first respondent had passed his compulsory retirement age and thus, deprived of such compensation. Again, in Jasman Saidin v Hotel Istana [2015] 3 ILR 299, the Industrial Court applied the Federal Court's ratio in Unilever (M) Holdings Sdn Bhd and held that as the claimant had already passed his compulsory retirement age when the award was made and hence, awarding compensation in lieu of reinstatement does not arise.

It is submitted that an employee should not be made to bear the burden of delay in the disposal of unfair dismissal claims referred to the Industrial Relations Department, the Minister of Human Resources and the Industrial Court pursuant to section 20 of the IRA. The delay would be more critical when there is a judicial review application to the High Court, the Court of Appeal and the Federal Court. To deprive the claimant who was dismissed nearing his compulsory retirement of the compensation in lieu of reinstatement, it is highly possible that the employer may obstruct the speedy disposal of the unfair dismissal claim by adopting the delaying tactics such as seeking unnecessary adjournment, raising preliminary objections and contesting the Industrial Court's award in the civil courts, among others. Thus, the question was rightly asked by lan $\mathrm{HC}$ Chin $J$ (as he then was) in Telekom Malaysia Bhd v Ramli Akim [2005] 6 CLJ 487, 'why should the employee be made to suffer for the delay of the process in establishing the employer's original wrongdoing. 
It is also worth noting that the Federal Court in Unilever (M) Holdings had left unresolved the following questions namely, whether compensation ought to be reduced when the claimant was nearing his compulsory retirement when the award was handed down, and whether such compensation is payable to an employee who could not be reinstated due to medical grounds arising subsequent to the dismissal for example, permanent physical or mental ill-health or infirmity impairing his ability from following normal employment. As noted earlier, the ratio in Unilever (M) Holdings Sdn Bhd is limited to a claimant who had attained his compulsory retirement age when the awarded was made and thus, whether it could be extended to situations mentioned above remains to be seen.

\section{BACK WAGES}

Back wages is awarded to an unjustly dismissed workman, irrespective whether he is awarded reinstatement or compensation in lieu of reinstatement. It is awarded primarily to compensate the workman for the period that he had been unemployed because of his dismissal. The assessment is provided in the Industrial Court's practice directive of 1987 namely, from the date of dismissal to the last date of the hearing subject to the maximum of 24 months. The rational of limiting back wages to 24 months was aptly noted by the Industrial Court in Nestle Food Storage (Sabah) Sdn Bhd v Terrence Tan Nyang Yin, namely, that within the 24 months of the unfair dismissal, the aggrieved workman will be able to secure alternative employment elsewhere that offers similar or better earning capacity. Further, the employer should not be penalised for the delay in the disposal of unfair dismissal claims under section 20(3) of the IRA.

It may be added, that in the case of a probationer, since he holds no lien to the appointment, any back wages given shall not exceed twelve months' back wages from the date of his dismissal based on his last drawn monthly salary. It is noteworthy that in Nada Pakar Sdn Bhd v Radja Aritonang [2001] 3 ILR 58, the Industrial Court held inter alia, that a probationer has no substantive right or lien to the post which he tentatively holds. He has no right of tenure to his job beyond the agreed contractual probationary period. It may be further added that the second Schedule of the Industrial Relations Act 1967 provide that the probationer would be awarded back wages not exceeding 12 months. The IRA also requires the Industrial Court to scale down back wages to such proportion as is just and equitable. This reduction can be made when there was a post dismissal earning after the dismissal and when the claimant had caused or contributed to his own predicament.

\subsection{Post Dismissal Earning}

The post-dismissal earning is a common law principle that requires a wrongfully dismissed workman to make reasonable exertion and show diligence in endeavouring to procure alternative employment. Failure to accept suitable alternative employment or take reasonable steps to procure the same would result in a deduction from the total amount recoverable calculated on a sum representing the amount the workman might have earned during the period. Where a workman is unable to secure a comparable job or where a comparable job did not exist having regard to the nature of his responsibilities and skill requirement, rate of pay and the location, he is not bound to accept employment with less attractive perks or lower fringe benefits. His back wages will not be subject to a reduction. The burden is on the employer to present credible evidence that it was more likely than not that the workman failed to mitigate the loss, and the court will consider the steps taken by the workman to mitigate the loss.

The post dismissal earning would be taken into account to off-set against any compensation otherwise recoverable. In Dr James Alfred, Sabah v Koperasi Serbaguna Sanya Bhd, Sabah \& Anor [2001] 3 CLJ 541, the Federal Court held inter alia, that taking into account of such employment after dismissal does not necessarily mean that the Industrial Court has to conduct a mathematical exercise in the deduction. What is important is that when assessing the quantum of back wages, the Industrial Court should take into account all relevant matters including the fact that the workman has been gainfully employed elsewhere after his dismissal.

The Federal Court's ratio in Dr James Alfred's case is now reflected in the second schedule to the IRA which provides that 'where there is post-dismissal earnings, a percentage of such earnings, to be decided by the Court, shall be deducted from the back wages given.' The emphasis here is 'a percentage of such earnings' and 'to be decided by the Court'. Thus, the appropriate percentage of the deduction from the post dismissal earnings is at the discretion of the Industrial Court to be decided based on the facts and circumstances of the individual case. However, in many of the Industrial Court's awards, the deduction for the post dismissal earning is arrived at based on a certain percentage without any reasons assigned as to why the said percentage was taken.

Further, if the claimant was unemployed for a considerable long period since his dismissal, only a small percentage of the post dismissal earning will be deducted. However, if the claimant had found alternative employment soon after his dismissal, the percentage of deduction would be substantial. For example, in Lechymy Supramaniam v DHL Global Forwarding (M) Sdn Bhd [2015] 2 LNS 1142, save for three months 
immediately after her dismissal, the claimant was gainfully employed for about two years since his dismissal with an initial salary of RM2,800.00 per month and later RM3,000.00 per month which was in fact lesser then what the claimant earned from the respondent namely, RM3,675.00. For the period she was unemployed, the Industrial Court awarded the claimant a sum of RM11,025.00 calculated on the basis of 3 months back wages $x \mathrm{RM}, 675.00$ (the last drawn monthly salary). For the period she was gainfully employed, the claimant was awarded a sum of RM61,740.00 calculated on the basis of 21 months $x$ RM3,675.00 less $20 \%$. The deduction from the post dismissal earning based on a certain percentage is further illustrated with reference to the Industrial Court's award as contained in the table below.

\subsection{Claimant's Contributory Conduct}

Where a dismissal was due to misconduct such as insubordination, disobedience, riotous and disorderly behaviour, damage to property, to name but a few, but the Court held the dismissal to be without just cause or excuse due to lack of warning, a domestic hearing, or held against the rule of natural justice, among others, it may be a clear case for reduction of the back wages: See Wong Yuen Hock $v$ Syarikat Hong Leong Assurance Sdn Bhd \& Another Appeal [1995] 3 CLJ 344. The IRA provides inter alia, that the Industrial Court must consider the unsatisfactory or contributory conduct of the employee or the extent to which his action contributed towards the situation that gave rise to the dismissal.

The extent of the reduction for the claimant's contributory conduct would depend on the detail facts of the individual case. The burden is on the employer to prove the claimant's contributory conduct. Where no cogent evidence was adduced to establish the claimant's contributory conduct, the Industrial Court will hold that that the claimant has not contributed towards his dismissal and hence, no deduction would be made from his back wages. It must be added that a bare allegation of misconduct against the claimant without sufficient evidence to prove that he had committed the acts of misconduct may not on its own warrant a reduction of the back wages.

In reality, however, the deduction of back wages due for the claimant's contributory conduct towards his dismissal is often arbitrary thus, involving an element of intelligent guess. For example, in Teh Fook Wai $v$ Panasonic Manufacturing Malaysia Bhd [2012] 2 LNS 1183, the Industrial Court noted the claimant's acts of misconduct detailed in charges 1 to 5 . As the company's decision to dismiss the claimant was without regards to equity, good conscience and substantial merits of the case, the claimant's dismissal was held to be without just cause or excuse. In the premises, it was the finding of the Court that the punishment of dismissal in this case was rather harsh and was thus, set aside as being without just cause or excuse. In relation to the claimant's contributory conduct, the Industrial Court made a deduction of $50 \%$ from the claimant's back wages. In particular, YA Eddie Yeo Soon Chye, Chairman of the Industrial Court, stated:

'It is unassailable that the Claimant's acts of misconduct landed him into the series of charges preferred against him by the Respondent. The Claimant's transgression was sufficiently clear to be weighed up in regards to the measure of recompense to which the Claimant may be fully entitled to. The Claimant in good conscience and equity must be made to bear some percentage of responsibility for the acts of misconduct. In the circumstances of the Claimant's case, I am of the view that the Claimant contributed to the extent of $50 \%$ and the amount of back wages to be awarded shall be reduced accordingly.'

A brief analysis of the cases illustrated in the table below shows that the deduction for the claimant's post dismissal earning and his blameworthy conduct is determined not only according to the facts of the individual case but also based on the conscience of the learned chairman and is thus, often arbitrary. As John Selden's jibe aptly described it 'equity varies with the length of the chancellor's foot'. C.P. Mill, a prominent labour law scholar, was not in favour of this method of assessment which according to him "may lead one party or the other (or perhaps each of them) to believe that some of the merits of his case have been overlooked" (C.P. Mill). It is obvious where in some cases where a claimant was diligent in securing gainful employment soon after the dismissal which offers the same or better terms of remuneration has his award reduced substantially because of the rule on mitigation of loss. However, an employee who only secured employment many months after his dismissal or who secured employment soon after dismissal but with reduced pay from what he earned from his previous employment had his back wages reduced at a smaller percentage. The above is disclosed in the table below which is based on the selected awards of the Industrial Court made in favour of the claimant whose dismissal was declared to be without just cause or excuse. 
IJASOS- International E-Journal of Advances in Social Sciences, Vol.II, Issue 6, December 2016

\begin{tabular}{|c|c|c|c|c|c|c|}
\hline CASE & $\begin{array}{l}\text { COMPENSATION IN } \\
\text { LIEU OF } \\
\text { REINSTATEMENT }\end{array}$ & BACKWAGES & $\begin{array}{l}\text { LESS } \\
\text { POST DISMISSAL EARNING }\end{array}$ & $\begin{array}{l}\text { LESS CONTRIBUTORY } \\
\text { CONDUCT }\end{array}$ & $\begin{array}{l}\text { LESS } \\
\text { AMOUNT ALREADY } \\
\text { PAID TO } \\
\text { CLAIMANT AS } \\
\text { COMPENSATION }\end{array}$ & TOTAL AWARD \\
\hline $\begin{array}{l}\text { Nigel Gia Bala v Jaya } \\
\text { Front Management \& } \\
\text { Services Sdn Bhd } \\
\text { [2016] 2 ILR } 337 \\
\end{array}$ & $\begin{array}{l}\text { RM4,000 } \\
\text { (1 year of service) }\end{array}$ & $\begin{array}{l}\text { RM48,000 } \\
(12 \text { months } \times \text { RM4000) }\end{array}$ & $\begin{array}{l}\text { No deduction as no evidence } \\
\text { was tendered to show that the } \\
\text { claimant was in gainful } \\
\text { employment. }\end{array}$ & $\begin{array}{l}\text { No deduction as no } \\
\text { evidence tendered to show } \\
\text { claimant's contributory } \\
\text { conduct. }\end{array}$ & $\mathrm{RM} 4,000$ & $\mathrm{RM} 48,000$ \\
\hline $\begin{array}{l}\text { Sivabalan } \\
\text { Poobalasingam v } \\
\text { Kuwait Finance } \\
\text { House (Malaysia) } \\
\text { Berhad [2016] 1 ILR } \\
542\end{array}$ & $\begin{array}{l}\text { RM42,853 } \times 4 \text { months } \times \\
2=\text { RM342,824 } \\
\text { (4 years of service. The } \\
\text { Industrial Court } \\
\text { awarded the claimant } 2 \\
\text { months' salary for each } \\
\text { year of completed } \\
\text { service as punitive } \\
\text { compensation) }\end{array}$ & $\begin{array}{l}\text { RM771,354 for the period he } \\
\text { was unemployed (RM42,853 x } \\
18 \text { months) } \\
\text { RM218,550.30 for the period } \\
\text { he was gainfully employed } \\
\text { (RM42,853 x } 6 \text { months - } 15 \% \text { ) }\end{array}$ & $\begin{array}{l}15 \% \text { deduction from the back } \\
\text { wages for the period he was } \\
\text { gainfully employed (RM } 42,853 \\
\times 6 \text { months }-15 \% \text { ) }\end{array}$ & $\begin{array}{l}\text { No deduction as no } \\
\text { evidence tendered to show } \\
\text { claimant's contributory } \\
\text { conduct. }\end{array}$ & $\begin{array}{l}\text { RM213,546 as } \\
\text { redundancy } \\
\text { severance payout } \\
\text { and } 3 \text { months' salary } \\
\text { in lieu of notice. }\end{array}$ & RM1,119,182.30 \\
\hline $\begin{array}{l}\text { Chan Kuo Feng v } \\
\text { Purina Petcare (M) } \\
\text { Sdn Bhd [2016] } 1 \text { ILR } \\
388\end{array}$ & $\begin{array}{l}\text { RM76,000 } \\
(8 \text { years in service }= \\
\text { RM9,500 } \times 8)\end{array}$ & $\begin{array}{l}\text { RM38,000 (RM9,500 x } 4 \\
\text { months). }\end{array}$ & $\begin{array}{l}\text { Limiting back wages to } 4 \\
\text { months. Claimant gainfully } \\
\text { employed } 4 \text { months after the } \\
\text { dismissal with a salary higher } \\
\text { than his last drawn salary. }\end{array}$ & $\begin{array}{l}\text { RM } 15,200 \text { or } 40 \% \text { deduction } \\
\text { of back wages for the } \\
\text { claimant's contributory } \\
\text { misconduct }\end{array}$ & Nil & RM98,800 \\
\hline $\begin{array}{l}\text { Lim Seong Kin v } \\
\text { Squire Mech Sdn Bhd } \\
\text { [2016] } 1 \text { ILR } 126\end{array}$ & $\begin{array}{l}\text { RM45,000 (5 years in } \\
\text { service }=5 \text { months } x \\
\text { RM9,000) }\end{array}$ & $\begin{array}{l}\text { RM90,000 (Limiting back } \\
\text { wages to } 10 \text { months. } \\
\text { However, no specific reasons } \\
\text { assigned except to say that it } \\
\text { is fair in the circumstances of } \\
\text { the case.) }\end{array}$ & $\begin{array}{l}\text { No deduction as no evidence } \\
\text { was tendered to show that the } \\
\text { claimant was in gainful } \\
\text { employment. }\end{array}$ & $\begin{array}{l}\text { No deduction as no } \\
\text { evidence tendered to show } \\
\text { claimant's contributory } \\
\text { conduct. }\end{array}$ & Nil & RM135,000 \\
\hline $\begin{array}{l}\text { Roselina Abdullah v } \\
\text { Konsortium } \\
\text { Transnasional Berhad } \\
\text { [2015] } 4 \text { ILR } 642\end{array}$ & $\begin{array}{l}\text { No order for } \\
\text { compensation in lieu of } \\
\text { reinstatement as the } \\
\text { claimant only served the } \\
\text { company for the period } \\
\text { of } 7 \text { months. }\end{array}$ & $\begin{array}{l}\text { RM120,000 RM12,000 x } 10 \\
\text { months (Limiting back wages } \\
\text { to } 10 \text { months as the claimant } \\
\text { was a probationer at the time } \\
\text { of the dismissal). }\end{array}$ & $\begin{array}{l}\text { Claimant obtained } \\
\text { employment after dismissal } \\
\text { but no details of the said } \\
\text { employment produced before } \\
\text { the court. Hence, } 20 \% \\
\text { deduction of back wages was } \\
\text { considered reasonable } \\
\text { amount. }\end{array}$ & $\begin{array}{l}20 \% \text { from the back wages } \\
\text { deducted as there was } \\
\text { contributory misconducts on } \\
\text { the part of the claimant } \\
\text { which lead to the dismissal. }\end{array}$ & Nil & RM72,000 \\
\hline $\begin{array}{l}\text { Mohd Haniff Mohd } \\
\text { Sidek v Saujana } \\
\text { Hotel Sdn Bhd [2015] } \\
4 \text { ILR } 433\end{array}$ & $\begin{array}{l}\text { RM45,000 ( } 15 \text { years in } \\
\text { service i.e., } 15 \text { months } x \\
\text { RM3,000) }\end{array}$ & $\begin{array}{l}\text { RM72,000 (RM3,000 } \times 24 \\
\text { months) Back wages from the } \\
\text { date of dismissal ( } 10 \\
\text { November 2011) to the last } \\
\text { date of hearing ( } 11 \text { December } \\
\text { 2014) but limited to } 24 \\
\text { months. }\end{array}$ & $\begin{array}{l}\text { RM21,600 or } 30 \% \text { deduction } \\
\text { of the post-dismissal earnings } \\
\text { although the claimant was } \\
\text { gainfully employed elsewhere } \\
\text { three months after the } \\
\text { dismissal. However, quantum } \\
\text { of salary earned from new } \\
\text { employment was much less } \\
\text { than what he earned when he } \\
\text { was employed in the } \\
\text { company. }\end{array}$ & $\begin{array}{l}\text { No deduction as no } \\
\text { evidence tendered to show } \\
\text { claimant's contributory } \\
\text { conduct. }\end{array}$ & Nil & $\mathrm{RM} 95,400$ \\
\hline $\begin{array}{l}\text { Tham Chee Hung } v \\
\text { Koperasi Keng Chew } \\
\text { Sandakan Berhad } \\
\text { [2015] } 2 \text { LNS } 0946\end{array}$ & $\begin{array}{l}\text { RM82,584.00 ( } 31 \text { years } \\
\text { of service x RM2,664.00 } \\
\text { per month }\end{array}$ & $\begin{array}{l}\text { RM2664.00 } \times 24 \text { back wages } \\
\text { from the date of dismissal }\left(13^{\text {th }}\right. \\
\text { April } 2011) \text { to the last date of } \\
\text { hearing }\left(13^{\text {th }} \text { May } 2015\right) \text { but } \\
\text { limited to } 24 \text { months. }\end{array}$ & $\begin{array}{l}\text { Dismissal on the } 13^{\text {th }} \text { April } \\
2011 \text { but new employment } \\
\text { since early } 2014 \text {. Hence, back } \\
\text { wages scaled down by } 10 \% \\
\text { for post dismissal earnings. }\end{array}$ & $\begin{array}{l}\text { No deduction as no } \\
\text { evidence tendered to show } \\
\text { claimant's contributory } \\
\text { conduct. }\end{array}$ & Nil & RM140,126.40 \\
\hline
\end{tabular}




\section{CONCLUSION}

An unfairly dismissed employee will be awarded compensation for loss of employment. This includes compensation in lieu of reinstatement which is calculated at the rate of one month wages for each completed years of service and lost remuneration or back wages subject to maximum of 24 months ordinary time remuneration. The Federal Court in Unilever (M) Holdings case held inter alia, that the claimant who had passed his compulsory retirement age when the Industrial Court handed down the award will be disentitled to get compensation in lieu of reinstatement. The authors humble submits that the above decision is very unfair to an employee who had served the company for many years but was dismissed from employment nearing his compulsory retirement. Should he succeed in his claim for unfair dismissal against the employer and were he to pass the retirement age when the award was made, he would not be eligible for such compensation. The argument is why the employee be made to bear the burden of delay in the disposal of unfair dismissal claims referred to the Industrial Relations Department, the Minister of Human Resources and the Industrial Court pursuant to section 20 of the IRA. Further, to deprive a worker of such compensation, it is possible for the employer to obstruct the speedy disposal of the unfair dismissal claim by adopting the delaying tactics such as seeking unnecessary adjournment, raising preliminary objections and contesting the Industrial Court's award in the civil courts, among others.

Further, in determining the back wages in favour of the unfairly dismissed worker, the Industrial Court will have to consider the extent to which his actions caused or contributed towards the situation that gave rise to the dismissal and if those actions so require, it shall reduce the amount of back wages that otherwise may have been awarded, accordingly. In addition, the Court shall also apply the same rule concerning the duty of a person to mitigate his loss as applied to damages recoverable under the common law for wrongful dismissal. However, from a brief analysis of the Industrial Court's awards as illustrated in the table produced in this article, discloses that the deduction of the claimant's post dismissal earning and his blameworthy conduct is determined largely based on the conscience of the learned chairman and thus, often arbitrary. It is submitted that for reasons such as providing a better guide to subsequent parties and subsequent Industrial Court, it is surely not too much to ask of the Court to indicate the factors it considered relevant when reducing the claimant's back wages at a certain percentage.

\section{REFERENCE LIST}

Ali Mohamed, A.A. (2015). Compensation In Lieu Of Reinstatement: A Review of Unilever (M) Holdings Sdn Bhd v. So Lai \& Anor. Industrial Law Reports vol. 2.

Ali Mohamed, A.A. (2014). Dismissal from Employment and the Remedies. LexisNexis (M) Sdn Bhd.

Ali Mohamed, A.A. (2005). Monetary Compensation In Dismissal Without Just Cause or Excuse: Legislative Guideline A Necessity. Malayan Law Journal vol. 6.

Anantaraman, V. (2005) Relief for Unfair Dismissals: Law And Practice In Malaysia. Malayan Law Journal vol. 6.

Kaur Bhatt, Jashpal. (2015). Should Compensation In Lieu Of Reinstatement Be Denied On The Basis Of Age? Revisiting the Federal Court's Decision in Unilever (M) Holdings Sdn Bhd v. So Lai @ Soo Boon Lai \& Anor [2015] 2 ILR 265, [2015] 3 CLJ 900. Industrial Law Reports vol. 4.

C.P. Mill, Industrial Disputes Law in Malaysia $2^{\text {nd }}$ eds., (1984) at p. 141. 